\title{
Comparison of Methodologies to Estimate Dietary Cadmium Intake in an Italian Population
}

\author{
Tommaso Filippini $1,2,+\left(\mathbb{C}\right.$, Kristen Upson ${ }^{3,+}$, Giorgia Adani ${ }^{1,2}$, Carlotta Malagoli ${ }^{1,2}$, \\ Claudia Baraldi ${ }^{2}$, Bernhard Michalke ${ }^{4}$ and Marco Vinceti $1,2,5, * \mathbb{D}$ \\ 1 CREAGEN, Environmental, Genetic and Nutritional Epidemiology Research Center-Section of Public \\ Health, Department of Biomedical, Metabolic and Neural Sciences, University of Modena and Reggio Emilia, \\ 41125 Modena, Italy; tommaso.filippini@unimore.it (T.F.); giorgia.adani@unimore.it (G.A.); \\ carlotta.malagoli@unimore.it (C.M.) \\ 2 Department of Biomedical, Metabolic and Neural Sciences, University of Modena and Reggio Emilia, \\ 41125 Modena, Italy; claudia.baraldi@unimore.it \\ 3 Department of Epidemiology and Biostatistics, College of Human Medicine, Michigan State University, \\ East Lansing, MI 48824, USA; upsonkri@msu.edu \\ 4 Helmholtz Center Munich, German Research Center for Environmental Health GmbH, Research Unit \\ Analytical BioGeoChemistry, 85764 Neuherberg, Germany; bernhard.michalke@helmholtz-muenchen.de \\ 5 Department of Public Health, Boston University, Boston, MA 02118, USA \\ * Correspondence: marco.vinceti@unimore.it \\ + Both authors contributed equally to this manuscript.
}

Received: 2 March 2020; Accepted: 26 March 2020; Published: 27 March 2020

check for updates

\begin{abstract}
Cadmium is a metal that is toxic to humans, and the major source of cadmium exposure in the non-smoking general population is diet. To identify major food sources and lower exposure from diet, an accurate estimate of dietary cadmium intake is needed. Hence, the objectives of this study are to develop a method to assess dietary cadmium intake using a biomarker measurement and to improve the estimation of dietary cadmium intake when using a food frequency questionnaire (FFQ). In a random sample of an Italian population, we collected dietary habits by FFQ and measured cadmium in foods and beverages. These data were used to compute the estimated weekly dietary intake (WDI) of cadmium $(\mu \mathrm{g})$ by kilogram $(\mathrm{kg})$ of body weight $(\mathrm{bw})\left(\mathrm{WDI}_{\mathrm{FFQ}}\right)$. We also measured fasting serum cadmium levels by inductively-coupled plasma mass spectrometry. We used these data to develop a model for the estimation of the biomarker-derived dietary cadmium intake $\left(\mathrm{WDI}_{\mathrm{bio}}\right)$. In the 51 subjects recruited, the median level of serum cadmium was $0.041 \mu \mathrm{g} / \mathrm{L}$ (interquartile range (IQR): $0.030-0.054$ ). The median $\mathrm{WDI}_{\mathrm{FFQ}}$ and $\mathrm{WDI}_{\text {bio }}$ were $1.34 \mu \mathrm{g} / \mathrm{kg} \mathrm{bw} /$ week (IQR: 0.86-1.70) and $0.72 \mu \mathrm{g} / \mathrm{kg}$ bw/week (IQR: 0.55-1.11), respectively. The correlation between the two estimates was low-to-moderate $(\mathrm{r}=0.291)$. In exploratory analyses, the correlation was slightly higher in women and participants ages $<50$ years, and markedly higher in participants with body mass index $<25 \mathrm{~kg} / \mathrm{m}^{2}$ and smokers. Our approach allows for the dietary contribution to be isolated from the overall cadmium exposure measured with a biomarker; the estimated dietary cadmium intake was roughly similar to that estimated using the FFQ, especially in select subgroups. Future refinements to the biomarker-derived dietary cadmium intake approach should take into consideration additional sources of cadmium exposure, as well as factors affecting its absorption and metabolism.
\end{abstract}

Keywords: cadmium; food frequency questionnaire; biomarker; dietary intake; estimation

\section{Introduction}

Cadmium is a toxic metal with both carcinogenic [1-4] and non-carcinogenic adverse effects [5-7] in humans. Smoking and pollution of ambient air from motorized traffic or industrial sources are 
major contributors to cadmium exposure [8,9]. In non-occupationally exposed non-smokers, the major source of cadmium is dietary intake [10]. Therefore, the characterization and reduction of cadmium exposure through diet in the general population are warranted from the public health perspective. The Joint FAO/WHO Expert Committee on Food Additives (JECFA) adopted the provisional tolerable monthly intake (PTMI) of $25 \mu \mathrm{g} \mathrm{Cd} / \mathrm{kg}$ body weight/month [11], corresponding to a tolerable weekly intake (TWI) of approximately $6 \mu \mathrm{g} \mathrm{Cd} / \mathrm{kg}$ body weight/week. The European Food Safety Authority established a lower tolerable weekly intake of $2.5 \mu \mathrm{g} / \mathrm{kg}$ body weight to ensure a high level of protection for all consumers, especially vulnerable subgroups [10]. Thus, an accurate estimate of dietary cadmium intake is needed to identify major food sources and to lower exposure from diet.

Dietary exposure to cadmium may be assessed through direct measurement of intake through foods or indirectly by biomonitoring [12]. However, these approaches have limitations. Dietary assessment of cadmium intake is considered prone to substantial measurement error of actual intake because of the large variation of cadmium content in food samples [13]. Biomonitoring of cadmium level is generally considered a valid method for assessment of exposure [14]. However, it captures exposure to cadmium from all sources, not just dietary; the specific contribution of dietary intake and inhalation to the overall exposure is not specified. For these reasons, it is not surprising that some studies have reported low correlations between biomarkers and dietary assessment of cadmium exposure $[15,16]$. Such a correlation has been particularly low among those with a substantial source of non-dietary exposure to cadmium-smokers.

The objectives of this study, carried out in an Italian population, are (1) to develop a method to assess dietary cadmium intake using a biomarker measurement, and (2) to improve the methods for the assessment of dietary cadmium intake by using a food frequency questionnaire. We also sought to provide a common estimate, the weekly dietary intake of cadmium by kilogram body weight, either biomarker-derived or based on the direct dietary assessment.

\section{Methods}

\subsection{Study Population and Dietary Habits Assessment}

The methods for the recruitment of the study population have already been reported in detail [17,18]. To summarize, we accessed the databases of the Modena Municipality General Registry Office. After approval from the local Ethics Committee, we recruited a random sample of individuals, ages 35-70 years, residing in Modena, a municipality of approximately 180,000 inhabitants located in the Emilia-Romagna region of Northern Italy. Specifically, we randomly selected a list of eligible individuals from each sex- and age-specific subgroup of the Modena adult population, using the "sample" routine of the Stata- 11 statistical software (Stata Corp., College Station, TX, USA). We contacted 150 individuals by phone, asking for their participation in the study. Of those contacted, $34 \%(n=51)$ agreed to participate. These participants were invited to attend a visit at a Modena Health Unit facility for the collection of a morning, fasting blood sample, and for the completion of two questionnaires. One questionnaire collected information on demographic and lifestyle characteristics. The other questionnaire was a food frequency questionnaire (FFQ) developed within the European Prospective Investigation into Cancer and Nutrition (EPIC) [19]. The EPIC-FFQ is a self-administered semi-quantitative FFQ; we used the version specifically developed and validated for the central-northern Italy population [20]. It was designed to estimate the frequency and amount of consumption of 188 food items over the previous year and used photos of serving sizes to ensure proper completion by participants. Data collected by the FFQ allowed for the assessment of nutrient and contaminant intakes.

\subsection{Laboratory Analysis}

We determined the cadmium content in foods characteristic of the usual diet of a northern Italian population and listed in the EPIC-FFQ questionnaire, as previously described. [17,21]. Briefly, we collected food samples from local stores and large retailers in Reggio Emilia and Modena provinces 
from October 2016 to February 2017. To prevent metal contamination from food containers, we used plastic tubes or jars and plastic cutlery during the collection and storage before analysis. We quantified cadmium in food using inductively coupled plasma-mass spectrometry with a limit of detection of $0.007 \mu \mathrm{g} / \mathrm{kg}$ [22].

We also quantified cadmium in biologic specimens from study participants. We collected fasting blood samples in a plastic tube, which were immediately centrifuged at 1000x $g$ for $10 \mathrm{~min}$ and stored as serum aliquots of $1 \mathrm{~mL}$ at $-15{ }^{\circ} \mathrm{C}$ until use. We measured serum cadmium levels using inductively coupled plasma-sector field-mass spectrometry (ICP-sf-MS) at the laboratory of the Helmholtz Center Munich German Research Center for Environmental Health (Research Unit Analytical BioGeoChemistry, Neuherberg, Germany) [8,23]. Specifically, we transferred $1 \mathrm{~mL}$ of frozen serum aliquot from each study participant on dry ice. We slowly thawed the samples in a refrigerator at $4{ }^{\circ} \mathrm{C}$. We then vortexed and diluted samples 1:10 with Milli-Q water, which contained ${ }^{103} \mathrm{Rh}$ as the internal standard. The final ${ }^{103} \mathrm{Rh}$ concentration in the diluted serum samples was $1 \mu \mathrm{g} / \mathrm{L}$. $\mathrm{No} \mathrm{HNO}_{3}$ was added to serum samples as this would have precipitated proteins, resulting in the loss of analytes (Cd) and potentially clogging the ICP-nebulizer. We determined serum Cd levels using ICP-sf-MS (ELEMENT 2, Thermo Scientific, Bremen, Germany) for ${ }^{111} \mathrm{Cd}$ determination in low-resolution mode. Sample introduction was carried out using an ESI-Fast-system (Elemental Scientific, Mainz, Germany) connected to a Micromist nebulizer with a cyclone spray chamber. The radio frequency (RF) power was set to $1200 \mathrm{~W}$, the plasma gas was $15 \mathrm{~L} \mathrm{Ar} / \mathrm{min}$, and the nebulizer gas was approximately $0.9 \mathrm{~L}$ $\mathrm{Ar} / \mathrm{min}$ after daily optimization. The limit of quantification of the determination method was $18 \mathrm{ng} / \mathrm{L}$ related to native serum. Regular laboratory intercomparing studies (GEQUAS quality controls scheme and IRMM/EU certification campaign) as well as regular analysis of certificate material, namely ERM-BD-150 (skimmed milk powder from European Reference Materials-BD150), ERM-CD281 (rye grass from European Reference Materials-CD281), and Recipe RM ClinCal Plasma, were implemented for quality control [24-26]. The selection of CRMs was adopted according to sample matrix (e.g., plasma RM from Recipe Chemicals + Instruments $\mathrm{GmbH}$, Munich, Germany) and to comparable (low) concentrations to samples (e.g., Cd in CRM CD281 or ERM-BD-150).

\subsection{Data Analysis and Models for Dietary Cadmium Estimation}

We developed two methodologies to estimate dietary cadmium intake. The first one was based on dietary assessment. We combined data on the cadmium content of foods and beverages with data on the dietary habits of the study population from the EPIC-FFQ, as previously reported [22]. Briefly, we multiplied element contents measured in food $(\mu \mathrm{g} / \mathrm{kg})$ with the intake of food and beverages $(\mathrm{g} /$ week), to estimate the daily dietary intake (DDI) of cadmium from the FFQ (1a). We then estimated the weekly dietary intake (WDI) by kilogram (kg) of body weight (bw), by multiplying the daily value per seven days, and dividing for the weight of participants (1b).

The equations for the estimation of dietary cadmium intake from FFQ were:

$$
\begin{gathered}
\operatorname{DDI}_{\mathrm{FFQ}}(\mu \mathrm{g} / \text { day })=\sum \frac{\mathrm{Cd} \text { food content }(\mu \mathrm{g} / \mathrm{kg}) \times \text { food intake }(\mathrm{g} / \text { day })}{1000} \\
\mathrm{WDI}_{\mathrm{FFQ}}(\mu \mathrm{g} / \text { week })=\mathrm{DDI}_{\mathrm{FFQ}}(\mu \mathrm{g} / \text { day }) \times(7 \text { days } / \text { weight })
\end{gathered}
$$

The second methodology was based on biomarker levels, specifically the concentration of cadmium in serum. To estimate dietary cadmium from biomarker levels, we implemented the following steps:

1. We conducted linear regression, modeling serum levels of cadmium in relation to non-dietary determinants of cadmium concentration, namely, sex, age, and body mass index. From this regression model, we calculated the linear prediction of serum cadmium (sCd; Table S1).

2. We considered the ratio between total blood cadmium and circulated serum cadmium to be 10:1 (i.e., serum cadmium concentrations are considered to be $10 \%$ of whole-blood concentrations on average) [27]. 
3. We included both foods and beverages as dietary sources of cadmium intake. Based on previous studies [28-30], we set an average percentage of cadmium absorption of $5 \%$ in all participants after ingestion.

4. We adjusted serum cadmium concentrations to account for the contribution of smoking to cadmium exposure in participants with a heavy smoking habit and/or many years of smoking. First, we recoded smoking habits in the following manner. Former smokers were considered "non-smokers" if they quit more than 20 years before the date of sample collection. If they had quit in the past 20 years, former smokers were classified as "smokers" [31]. For this new category of "smokers", we calculated the pack/year according to the NCI definition [32] and considered a pack to contain 20 cigarettes as generally sold in Italy [32]. In one case of cigarillos smoking, one cigarillo was considered equal to two cigarettes [33]. Second, we calculated the ratio (R) of pack-years of smoking to the total age of the participant. We estimated the adjusted serum cadmium concentration by multiplying the serum cadmium concentration by this ratio $\mathrm{R}$ and subtracting the product from the total serum cadmium levels.

5. Lastly, we used the following equations to derive the dietary cadmium intake from the predicted serum cadmium:

$$
\begin{gathered}
\mathrm{WDI}_{\text {bio }}=[(\mathrm{sCd} \times 100 / 10) \times 100 / 5] \times(7 \text { days } / \text { weight }) \\
\mathrm{WDI}_{\text {bio }}=\{[(\mathrm{sCd}-(\mathrm{sCd} \times \mathrm{R})) \times 100 / 10] \times 100 / 5\} \times(7 \text { days } / \text { weight })
\end{gathered}
$$

where WDI is the estimated weekly dietary intake for never smokers ( $2 a)$ and for former and current smokers (2b); $s C d$ is the predicted serum cadmium level based on the linear regression adjusted for age, sex and body mass index; $\mathrm{R}$ is the ratio of pack-years of smoking to the total age of the participants.

We performed the data analyses using Stata (version 15.2, Stata Corp., College Station, TX, USA). Data are generally presented using median and interquartile range (IQR). Pearson's correlation ( $\mathrm{r}$ ) and its $95 \%$ confidence interval $(\mathrm{CI})$ were estimated to assess the correlation between $\mathrm{WDI}_{\mathrm{FFQ}}$ and $\mathrm{WDI}_{\mathrm{bio}}$ in the overall population.

We conducted exploratory analyses in which we estimated the $\mathrm{WDI}_{\mathrm{FFQ}}, \mathrm{WDI}_{\mathrm{bio}}$, and their correlation in select subgroups of participants. We conducted these analyses to explore whether the estimation of dietary cadmium intake using dietary data and a biologic measurement were constant by sex, age ( $<50$ and $\geq 50$ years), body mass index (BMI) $\left(<25\right.$ and $\left.\geq 25 \mathrm{~kg} / \mathrm{m}^{2}\right)$, and smoking status. For these analyses, smoking status was considered in two ways. We analyzed smoking habits as collected using the questionnaire in three categories (never-, former-, and current-smokers). We repeated the analyses using two categories (non-smokers and smokers) considering the long half-life of cadmium in blood; former smokers were categorized as "non-smokers" if they had quit 20 years or more before the sample collection, and as "smokers" if less they had quit in the past 20 years.

\section{Results}

The characteristics of study participants are reported in Table 1 . All the study participants $(n=51)$ were Caucasian with Italian citizenship. The age of the participants ranged between 35 and 71 years, with a median of 50 years (IQR: 44-62); 51\% of participants were male. With regard to smoking habits, twenty-six individuals were never smokers. The sixteen former smokers and nine current smokers had similar median pack-years of smoking. Serum cadmium levels in the overall population were 0.041 (IQR: $0.030-0.054) \mu \mathrm{g} / \mathrm{L}$, with slightly higher levels in participants younger than age 50 and those with a body mass index $\geq 25 \mathrm{~kg} / \mathrm{m}^{2}$ (Table 1 ). Greater serum cadmium concentrations were also observed among current and former smokers compared to never smokers. The median $\mathrm{WDI}_{\mathrm{FFQ}}$ and $\mathrm{WDI}_{\mathrm{bio}}$ were $1.34 \mu \mathrm{g} / \mathrm{kg} \mathrm{bw} /$ week (IQR: 0.86-1.70) and $0.76 \mu \mathrm{g} / \mathrm{kg}$ bw/week (IQR: 0.70-0.93), respectively (Table 2). A few participants $(n=3)$ had $\mathrm{WDI}_{\mathrm{FFQ}}$ estimates that were greater than $2.5 \mu \mathrm{g} / \mathrm{kg}$ bw/week, the tolerable value established by the Food Safety Authority of the European Union [10]. The correlation between $\mathrm{WDI}_{\mathrm{FFQ}}$ and $\mathrm{WDI}_{\text {bio }}$ was low-to-moderate ( $\mathrm{r}=0.291,95 \% \mathrm{CI}$ : 0.017 to 0.524$)$ in the overall population. The $\mathrm{WDI}_{\mathrm{FFQ}}$ estimate was higher than the $\mathrm{WDI}_{\text {bio }}$ estimate. 
Table 1. Characteristics of study population and cadmium serum median (interquartile range-IQR) levels $(\mu \mathrm{g} / \mathrm{L})$.

\begin{tabular}{|c|c|c|c|c|}
\hline Characteristics & $n$ & $(\%)$ & Median & IQR \\
\hline All subjects & 51 & $(100)$ & 0.041 & $0.030-0.054$ \\
\hline \multicolumn{5}{|l|}{ Sex } \\
\hline Men & 26 & (51) & 0.040 & $0.032-0.055$ \\
\hline Women & 25 & (49) & 0.041 & $0.030-0.054$ \\
\hline \multicolumn{5}{|l|}{ Age } \\
\hline$<50$ years & 23 & $(45)$ & 0.043 & $0.036-0.059$ \\
\hline$\geq 50$ years & 28 & (55) & 0.036 & $0.028-0.047$ \\
\hline \multicolumn{5}{|l|}{ Education } \\
\hline Primary school & 3 & (6) & 0.027 & $0.023-0.105$ \\
\hline Middle school & 10 & (20) & 0.040 & $0.030-0.048$ \\
\hline High school & 23 & (45) & 0.039 & $0.029-0.049$ \\
\hline College or more & 15 & (29) & 0.045 & $0.035-0.059$ \\
\hline \multicolumn{5}{|l|}{ Occupation } \\
\hline Industrial sector ${ }^{a}$ & 6 & $(12)$ & 0.044 & $0.037-0.059$ \\
\hline Services ${ }^{b}$ & 27 & (53) & 0.043 & $0.031-0.054$ \\
\hline Retired & 11 & (21) & 0.037 & $0.020-0.058$ \\
\hline Not employed & 7 & (14) & 0.036 & $0.030-0.048$ \\
\hline Body mass index & 25.2 & $(23.0-28.4)$ & & \\
\hline$<25 \mathrm{~kg} / \mathrm{m}^{2}$ & 23 & $(45)$ & 0.038 & $0.029-0.048$ \\
\hline$\geq 25 \mathrm{~kg} / \mathrm{m}^{2}$ & 28 & (55) & 0.043 & $0.031-0.061$ \\
\hline \multicolumn{5}{|l|}{ Smoking habits as reported } \\
\hline Never smokers & 26 & $(51)$ & 0.036 & $0.029-0.043$ \\
\hline Former smokers & 16 & (31) & 0.045 & $0.032-0.053$ \\
\hline Current smokers & 9 & (18) & 0.055 & $0.042-0.059$ \\
\hline Pack/year ${ }^{c}$ & 14.2 & $(6.8-19.0)$ & & \\
\hline Former smokers ${ }^{c}$ & 15.0 & $(5.5-19.5)$ & & \\
\hline Current smokers ${ }^{\mathrm{c}}$ & 13.5 & $(7.2-14.3)$ & & \\
\hline \multicolumn{5}{|l|}{ Smoking habits recoded ${ }^{\mathrm{d}}$} \\
\hline Non-Smokers & 37 & (73) & 0.037 & $0.030-0.046$ \\
\hline Smokers & 14 & (27) & 0.051 & $0.041-0.059$ \\
\hline
\end{tabular}

a Industrial sector includes engineering workers and chemical workers; ${ }^{\mathrm{b}}$ Health, education, and business; ${ }^{\mathrm{c}}$ Median (IQR); ${ }^{\text {d }}$ Smoking habits recoded with former smokers categorized as "non-smokers" if they quit 20 years or more before sample collection, and as "smokers" if they quit less than 20 years before sample collection.

In the exploratory analyses, $\mathrm{WDI}_{\mathrm{FFQ}}$ was higher in women $(1.38 \mu \mathrm{g} / \mathrm{kg}$ bw/week, IQR: 0.86-1.91), participants ages 50 years and older $(1.37 \mu \mathrm{g} / \mathrm{kg}$ bw/week, IQR: $0.87-1.69)$, those with BMI $<25$ $(1.38 \mu \mathrm{g} / \mathrm{kg}$ bw/week, IQR: 0.86-1.99), and non-smokers (1.37 $\mu \mathrm{g} / \mathrm{kg}$ bw/week, IQR: 0.86-1.74) (Table 2). With regard to $\mathrm{WDI}_{\mathrm{bio}}$, it was similar between men and women and categories of BMI, and higher in participants ages $<50$ years $(0.93 \mu \mathrm{g} / \mathrm{kg}$ bw/week, IQR: $77-1.07)$, and non-smokers $(0.78 \mu \mathrm{g} / \mathrm{kg}$ bw/week, IQR: 73-1.32). A higher intake was observed for former smokers compared to never-smokers using $\mathrm{WDI}_{\mathrm{FFQ}}$, but not $\mathrm{WDI}_{\text {bio }}$. The correlation between $\mathrm{WDI}_{\mathrm{FFQ}}$ and $\mathrm{WDI}_{\mathrm{bio}}$ was slightly higher in women ( $r=0.352,95 \%$ CI: -0.050 to 0.656$)$ and participants $<50$ years ( $r=0.370,95 \%$ CI: -0.050 to 0.679 ), and markedly higher in participants with a BMI $<25$ ( $\mathrm{r}=0.555,95 \% \mathrm{CI}: 0.185$ to 0.787$)$. Correlations differed across smoking habit categories with higher correlation in smokers $(\mathrm{r}=0.520,95 \% \mathrm{CI}:-0.014$ to 0.824$)$ and a lower correlation in non-smokers $(r=0.244,95 \%$ CI: -0.087 to 0.625$)$.

Sensitivity analyses using a cutpoint of 10 years since quitting smoking instead of 20 years for the categorization of non-smokers and smokers did not substantially change the results of $\mathrm{WDI}_{\mathrm{FFQ}}$ and $\mathrm{WDI}_{\mathrm{bio}}$; we observed similar values for non-smokers and smokers (Table S2). Using the 20-years categorization, we observed a WDI ${ }_{F F Q}$ of $1.37 \mu \mathrm{g} / \mathrm{kg} \mathrm{bw} /$ week and a $W_{\text {Dio }}$ of $0.78 \mu \mathrm{g} / \mathrm{kg} \mathrm{bw} /$ week. The corresponding estimates using the 10-years categorization were 1.17 and $0.68 \mu \mathrm{g} / \mathrm{kg} \mathrm{bw} /$ week for 
$\mathrm{WDI}_{\mathrm{FFQ}}$ and $\mathrm{WDI}_{\mathrm{bio}}$, respectively. When we considered a lower absorption rate for cadmium (3\%) in Equations $(2 \mathrm{a}, \mathrm{b})$, estimates of dietary cadmium intake from the biomarker-derived estimate $\mathrm{WDI}_{\mathrm{bio}}$ slightly increased. To reach the same level in serum of cadmium, a higher intake of cadmium is needed, thus the estimation of dietary intake from biomarker increases when the percentage of absorption decreases (Table S2).

Table 2. Estimated weekly dietary intake (median (50th) and interquartile range (IQR) reported in $\mu \mathrm{g}$ per kilograms of body weight per week) using food frequency questionnaire (WDI $\mathrm{FFQ}_{\mathrm{F}}$ ) and serum cadmium biomarker levels ( $\mathrm{WDI}_{\text {bio }}$ ) in select subgroups, and Pearson's correlation (r) with 95\% confidence interval $(\mathrm{CI})$ between $\mathrm{WDI}_{\mathrm{FFQ}}$ and $\mathrm{WDI}_{\text {bio. }}$.

\begin{tabular}{|c|c|c|c|c|c|c|c|c|}
\hline \multirow{2}{*}{ Subgroups } & \multicolumn{3}{|c|}{ WDI $_{\mathrm{FFQ}}$} & \multicolumn{3}{|c|}{$\mathrm{WDI}_{\text {bio }}$} & \multicolumn{2}{|c|}{$\begin{array}{c}\text { Correlation } \\
\text { WDI }_{\mathrm{FFQ}}-\mathrm{WDI}_{\text {bio }}\end{array}$} \\
\hline & 50th & (IQR) & Range & 50th & (IQR) & Range & $\mathbf{r}$ & $(95 \%$ CI) \\
\hline All subjects & 1.34 & $0.86-1.70$ & $0.26-3.18$ & 0.76 & $0.70-0.93$ & $0.33-1.32$ & 0.291 & $(0.017,0.524)$ \\
\hline \multicolumn{9}{|l|}{ Sex } \\
\hline Men & 1.30 & $(0.87-1.63)$ & $0.26-3.18$ & 0.76 & $(0.70-0.93)$ & $0.33-1.08$ & 0.214 & $(-0.189,0.556)$ \\
\hline Women & 1.38 & $(0.86-1.91)$ & $0.30-3.07$ & 0.77 & $(0.70-0.93)$ & $0.33-1.32$ & 0.352 & $(-0.050,0.656)$ \\
\hline \multicolumn{9}{|l|}{ Age } \\
\hline$<50$ years & 1.29 & $(0.80-2.15)$ & $0.26-3.07$ & 0.93 & $(0.77-1.07)$ & $0.41-1.32$ & 0.370 & $(-0.050,0.679)$ \\
\hline$\geq 50$ years & 1.37 & $(0.87-1.69)$ & $0.30-3.18$ & 0.73 & $(0.69-0.77)$ & $0.33-0.93$ & 0.233 & $(-0.154,0.557)$ \\
\hline \multicolumn{9}{|l|}{ Body mass index } \\
\hline$<25 \mathrm{~kg} / \mathrm{m}^{2}$ & 1.38 & $(0.86-1.99)$ & $0.59-3.07$ & 0.78 & $(0.70-0.93)$ & $0.33-1.23$ & 0.555 & $(0.185,0.787)$ \\
\hline$\geq 25 \mathrm{~kg} / \mathrm{m}^{2}$ & 1.21 & $(0.84-1.62)$ & $0.26-3.18$ & 0.75 & $(0.71-0.92)$ & $0.41-1.32$ & 0.112 & $(-0.273,0.465)$ \\
\hline \multicolumn{9}{|l|}{ Smoking habits } \\
\hline Never-smokers & 1.27 & $(0.73-1.60)$ & $0.26-3.07$ & 0.86 & $(0.75-0.99)$ & $0.62-1.32$ & 0.371 & $(-0.020,0.663)$ \\
\hline Former-smokers & 1.66 & $(1.24-1.95)$ & $0.62-3.18$ & 0.75 & $(0.71-0.80)$ & $0.33-0.93$ & 0.416 & $(-0.101,0.756)$ \\
\hline Current-smokers & 1.17 & $(1.03-1.36)$ & $0.72-1.55$ & 0.68 & $(0.59-0.74)$ & $0.33-0.96$ & 0.406 & $(-0.354,0.843)$ \\
\hline \multicolumn{9}{|c|}{ Smoking habits recoded ${ }^{\mathrm{a}}$} \\
\hline Non-smokers & 1.37 & $(0.86-1.74)$ & $0.26-3.18$ & 0.78 & $(0.73-1.32)$ & $0.33-1.32$ & 0.244 & $(-0.087,0.625)$ \\
\hline Smokers & 1.24 & (1.03-1.55) & $0.62-2.32$ & 0.68 & $(0.59-0.74)$ & $0.33-0.96$ & 0.520 & $(-0.014,0.824)$ \\
\hline
\end{tabular}

\section{Discussion}

In this study, we sought to assess dietary cadmium exposure in an Italian population by comparing two methods to estimate it: one based on the modeling of serum cadmium levels and the other based on a validated food frequency questionnaire. Our results showed a generally low-to-moderate correlation between the two methodologies. In addition, we noted that the median $\mathrm{WDI}_{\mathrm{FFQ}}$ was higher than the median $\mathrm{WDI}_{\text {bio }}$.

The low-to-moderate correlation between the two indicators may be due to several factors. First, we measured cadmium levels in serum instead of whole blood, using the information on the percent of cadmium bound to erythrocytes, which is generally $90 \%$ [27]. However, the binding of cadmium to metallothionein or to other plasma proteins may differ, and we did not account for these differences in our estimation of dietary cadmium intake using serum cadmium. Second, it is possible that a different rate of absorption of dietary cadmium may have affected the correlation between $\mathrm{WDI}_{\mathrm{FFQ}}$ and $\mathrm{WDI}_{\text {bio }}$ [30]. However, the correlation between two WDIs was not altered in our sensitivity analysis using an alternative absorption rate. Third, we did not consider cadmium excretion in our estimation of $\mathrm{WDI}_{\text {bio. }}$. Following dietary exposure, cadmium accumulates in the kidney and is slowly released into the urine. In subjects with kidney disease, excretion may be slower, thus increasing cadmium body burden [34]. In the present study, none of the study participants reported a history of major disease, including kidney disease, at the time of blood sampling. Therefore, the concern for kidney disease affecting the results is minimal. In addition, dietary exposure to cadmium does not appear high enough to increase the incidence of chronic kidney disease [35]. Fourth, other sources of cadmium may contribute to serum cadmium levels that were not accounted for in our estimation of the $\mathrm{WDI}_{\mathrm{bio}}$ such as occupational exposure or inhalation of cadmium from indoor contaminants (such as passive 
smoking or cooking fumes), and outdoor air pollutants [8,36-38]. Fifth, we were not able to consider the status of other elements, for example, body iron stores, selenium, or other trace elements, which may interfere with cadmium absorption and metabolism. [30,39-42]. Lastly, the overestimation of the intake of foods that contribute to cadmium intake is possible. Foods generally considered healthy are more likely to be remembered, especially when people are confronted with dietary studies and nutritionist [43]. Since cereals and vegetables are the main source of cadmium in foods [22], it is possible that we overestimated the $\mathrm{WDI}_{\mathrm{FFQ}}$.

In previous studies, the correlation between dietary exposure to cadmium based on dietary assessment and biomarker measurements have ranged from -0.10 to $0.61[15,16,39,44-50]$. Although two duplicate studies where urine samples were collected within $24 \mathrm{~h}$ of dietary assessment yielded a moderate correlation $(0.40)[39,47]$, the correlation in other studies has been low $[16,48,49]$. This is likely due to the measurement of cadmium in urine characterizing long-term exposure (over several years or decades), whereas the dietary assessment captured recent dietary exposure. Our approach to disentangling the dietary contribution to cadmium exposure using biomarker measurements provides for a fairer comparison between biomarker measurement and dietary assessment.

Three prior studies to our knowledge have developed approaches to estimate cadmium intake from biomarkers. One study conducted in Japan, similar to our study, proposed a method using linear regression to estimate daily cadmium intake from biological sample levels. In that study, however, confounding by smoking seemed to be minimal to null, especially with regard to urinary cadmium levels [51]. When the linear regression models for the estimation of dietary cadmium from blood or urinary cadmium were applied to populations in East Asian countries, correlation coefficients above 0.7 were observed; the correlations were particularly high in female participants for whom the low smoking prevalence may have minimized confounding compared to males [52]. Another study with Swedish non-smoking women compared toxicokinetic models to estimate cadmium intake from urinary cadmium. The findings from that study suggest that, instead of an eight-compartment model based on many equations taking into account cadmium absorption, transport, and excretion [45], the use of a simpler one-compartment model based on kidney accumulation and excretion may adequately estimate cadmium intake [53]. Similar to the previous studies, we developed a method for the estimation of cadmium intake using linear regression and including non-dietary determinants (namely age, sex, and body mass index) in the model. We also attempted to account for smoking habits by developing different equations for smokers and non-smokers.

A strength of our study is the estimation of $\mathrm{WDI}_{\mathrm{FFQ}}$ using a validated food frequency questionnaire (FFQ) version that was developed and validated for the central-northern Italy population [20]. This was complemented by our measurement of cadmium in foods commonly consumed by the study population [22]. Our study additionally benefitted from the recruitment of a representative sample of residents from the Modena municipality [8,54]. The characteristics of our study population are similar to those of the overall Italian and regional population [55,56], strengthening the external validity of our results. Despite these strengths, this study was limited by the small sample size and limited age range (35-70 years). This resulted in less precise estimates, and, therefore, replication of this study in a larger study population is warranted.

Contamination of food and beverages from toxic metals like cadmium represents an important public health issue, especially in heavily contaminated areas [12]. Although staple foods generally contribute to only $40-60 \%$ of total dietary cadmium intake, dietary cadmium exposure can occur from the intake of food with substantial cadmium content, such as seafood, mushrooms, offal, and chocolate [4,22,57-61]. Avoidance or limitation of consumption of these foods, especially in vulnerable populations like children, pregnant women, or elderly people, is highly advisable [12,62]. Therefore, an adequate assessment of their dietary intake is of utmost importance, as well as the ability to compare actual exposure with the safety values set by international agencies [10,60]. It should be noted that in our study, some participants had $\mathrm{WDI}_{\mathrm{FFQ}}$ estimates that exceeded the tolerable value of $2.5 \mu \mathrm{g} / \mathrm{kg}$ bw/week established by the Food Safety Authority of the European Union [10]. 


\section{Conclusions}

In this study, we present an approach to isolate the dietary contribution to cadmium exposure from a biomarker measurement, accounting for smoking habits. The biomarker-based approach yielded roughly similar estimates of the weekly dietary intake of cadmium to that derived from dietary assessment by an FFQ. Despite the study limitations, our methods could be useful in a scenario in which the estimation of dietary cadmium intake is sought for risk assessment, but only a biomarker of cadmium is available. Future refinements to this modeling should take into consideration additional sources of cadmium exposure, as well as factors affecting its absorption and metabolism.

Supplementary Materials: The following are available online at http://www.mdpi.com/1660-4601/17/7/2264/s1, Table S1: Linear regression coefficients (Beta) and 95\% confidence intervals (CI) between serum cadmium and relevant confounders for adjustment levels, Table S2: Estimated weekly dietary intake (median (50th) and interquartile range (IQR) reported in $\mu \mathrm{g}$ per kilograms of body weight per week) using food frequency questionnaire $\left(\mathrm{WDI}_{\mathrm{FFQ}}\right)$ and using serum cadmium biomarker levels $\left(\mathrm{WDI}_{\mathrm{bio}}\right)$ in total population and in select subgroups considering a value of $3 \%$ for cadmium absorption in Equations $(2 a, b)$.

Author Contributions: Conceptualization: T.F., M.V., and K.U.; Methodology: T.F., B.M., M.V., and K.U.; Formal Analysis: T.F. and B.M.; Investigation: G.A., T.F., B.M., and C.M.; Data Curation: G.A., C.B., T.F., B.M., and C.M.; Writing-Original Draft Preparation: T.F., M.V., and K.U.; Writing-Review and Editing, all authors. All authors have read and agreed to the published version of the manuscript.

Funding: This work was supported by a grant "Dipartimenti di Eccellenza 2018-2022, MIUR, Italy" to the Department of Biomedical, Metabolic and Neural Sciences and by the Local Health Authority of Reggio Emilia. This work was also supported by the National Institute of Nursing Research of the National Institutes of Health (grant R00NR017191 to K.U.). The content is solely the responsibility of the authors and does not necessarily represent the official views of the National Institutes of Health.

Conflicts of Interest: The authors declare no conflict of interest.

\section{References}

1. Vinceti, M.; Venturelli, M.; Sighinolfi, C.; Trerotoli, P.; Bonvicini, F.; Ferrari, A.; Bianchi, G.; Serio, G.; Bergomi, M.; Vivoli, G. Case-control study of toenail cadmium and prostate cancer risk in Italy. Sci. Total Environ. 2007, 373, 77-81. [CrossRef] [PubMed]

2. Jablonska, E.; Socha, K.; Reszka, E.; Wieczorek, E.; Skokowski, J.; Kalinowski, L.; Fendler, W.; Seroczynska, B.; Wozniak, M.; Borawska, M.H.; et al. Cadmium, arsenic, selenium and iron: Implications for tumor progression in breast cancer. Environ. Toxicol. Pharmacol. 2017, 53, 151-157. [CrossRef] [PubMed]

3. Van Maele-Fabry, G.; Lombaert, N.; Lison, D. Dietary exposure to cadmium and risk of breast cancer in postmenopausal women: A systematic review and meta-analysis. Environ. Int. 2016, 86, 1-13. [CrossRef] [PubMed]

4. Arnich, N.; Sirot, V.; Riviere, G.; Jean, J.; Noel, L.; Guerin, T.; Leblanc, J.C. Dietary exposure to trace elements and health risk assessment in the 2nd French Total Diet Study. Food Chem. Toxicol. 2012, 50, 2432-2449. [CrossRef] [PubMed]

5. Satarug, S.; Vesey, D.A.; Gobe, G.C. Kidney Cadmium Toxicity, Diabetes and High Blood Pressure: The Perfect Storm. Tohoku J. Exp. Med. 2017, 241, 65-87. [CrossRef] [PubMed]

6. Tinkov, A.A.; Filippini, T.; Ajsuvakova, O.P.; Aaseth, J.; Gluhcheva, Y.G.; Ivanova, J.M.; Bjorklund, G.; Skalnaya, M.G.; Gatiatulina, E.R.; Popova, E.V.; et al. The role of cadmium in obesity and diabetes. Sci. Total Environ. 2017, 601-602, 741-755. [CrossRef]

7. Tinkov, A.A.; Filippini, T.; Ajsuvakova, O.P.; Skalnaya, M.G.; Aaseth, J.; Bjorklund, G.; Gatiatulina, E.R.; Popova, E.V.; Nemereshina, O.N.; Huang, P.T.; et al. Cadmium and atherosclerosis: A review of toxicological mechanisms and a meta-analysis of epidemiologic studies. Environ. Res. 2018, 162, 240-260. [CrossRef]

8. Filippini, T.; Michalke, B.; Malagoli, C.; Grill, P.; Bottecchi, I.; Malavolti, M.; Vescovi, L.; Sieri, S.; Krogh, V.; Cherubini, A.; et al. Determinants of serum cadmium levels in a Northern Italy community: A cross-sectional study. Environ. Res. 2016, 150, 219-226. [CrossRef]

9. Pan, J.; Plant, J.A.; Voulvoulis, N.; Oates, C.J.; Ihlenfeld, C. Cadmium levels in Europe: Implications for human health. Environ. Geochem. Health 2010, 32, 1-12. [CrossRef] 
10. European Food Safety Authority. Cadmium dietary exposure in the European population. EFSA J. 2012, 10, 2551. [CrossRef]

11. JECFA. Cadmium. In Safety Evaluation of Certain Food Additives and Contaminants; Joint FAO/WHO Expert Committee on Food Additives, Ed.; WHO: Geneva, Switzerland, 2011.

12. Satarug, S.; Vesey, D.A.; Gobe, G.C. Health risk assessment of dietary cadmium intake: Do current guidelines indicate how much is safe? Environ. Health Perspect. 2017, 125, 284-288. [CrossRef] [PubMed]

13. Satarug, S. Dietary Cadmium Intake and Its Effects on Kidneys. Toxics 2018, 6, 15. [CrossRef] [PubMed]

14. Satarug, S.; Vesey, D.A.; Ruangyuttikarn, W.; Nishijo, M.; Gobe, G.C.; Phelps, K.R. The Source and Pathophysiologic Significance of Excreted Cadmium. Toxics 2019, 7, 55. [CrossRef] [PubMed]

15. Vacchi-Suzzi, C.; Eriksen, K.T.; Levine, K.; McElroy, J.; Tjonneland, A.; Raaschou-Nielsen, O.; Harrington, J.M.; Meliker, J.R. Dietary Intake Estimates and Urinary Cadmium Levels in Danish Postmenopausal Women. PLoS ONE 2015, 10, e0138784. [CrossRef]

16. Quraishi, S.M.; Adams, S.V.; Shafer, M.; Meliker, J.R.; Li, W.; Luo, J.; Neuhouser, M.L.; Newcomb, P.A. Urinary cadmium and estimated dietary cadmium in the Women's Health Initiative. J. Expo. Sci. Environ. Epidemiol. 2016, 26, 303-308. [CrossRef]

17. Filippini, T.; Ferrari, A.; Michalke, B.; Grill, P.; Vescovi, L.; Salvia, C.; Malagoli, C.; Malavolti, M.; Sieri, S.; Krogh, V.; et al. Toenail selenium as an indicator of environmental exposure: A cross-sectional study. Mol. Med. Rep. 2017, 15, 3405-3412. [CrossRef]

18. Vinceti, M.; Grill, P.; Malagoli, C.; Filippini, T.; Storani, S.; Malavolti, M.; Michalke, B. Selenium speciation in human serum and its implications for epidemiologic research: A cross-sectional study. J. Trace Elem. Med. Biol. 2015, 31, 1-10. [CrossRef]

19. Pala, V.; Sieri, S.; Palli, D.; Salvini, S.; Berrino, F.; Bellegotti, M.; Frasca, G.; Tumino, R.; Sacerdote, C.; Fiorini, L.; et al. Diet in the Italian EPIC cohorts: Presentation of data and methodological issues. Tumori 2003, 89, 594-607. [CrossRef]

20. Pasanisi, P.; Berrino, F.; Bellati, C.; Sieri, S.; Krogh, V. Validity of the Italian EPIC questionnaire to assess past diet. IARC Sci. Publ. 2002, 156, 41-44.

21. Turrini, A.; Saba, A.; Perrone, D.; Cialfa, E.; D'Amicis, A. Food consumption patterns in Italy: The INN-CA Study 1994-1996. Eur J. Clin. Nutr. 2001, 55, 571-588. [CrossRef]

22. Filippini, T.; Cilloni, S.; Malavolti, M.; Violi, F.; Malagoli, C.; Tesauro, M.; Bottecchi, I.; Ferrari, A.; Vescovi, L.; Vinceti, M. Dietary intake of cadmium, chromium, copper, manganese, selenium and zinc in a Northern Italy community. J. Trace Elem. Med. Biol. 2018, 50, 508-517. [CrossRef] [PubMed]

23. Junemann, A.G.; Stopa, P.; Michalke, B.; Chaudhri, A.; Reulbach, U.; Huchzermeyer, C.; Schlotzer-Schrehardt, U.; Kruse, F.E.; Zrenner, E.; Rejdak, R. Levels of aqueous humor trace elements in patients with non-exsudative age-related macular degeneration: A case-control study. PLoS ONE 2013, 8, e56734. [CrossRef] [PubMed]

24. Filippini, T.; Michalke, B.; Grill, P.; Malagoli, C.; Malavolti, M.; Vescovi, L.; Sieri, S.; Krogh, V.; Cherubini, A.; Maffeis, G.; et al. Determinants of serum manganese levels in an Italian population. Mol. Med. Rep. 2017, 15, 3340-3349. [CrossRef] [PubMed]

25. ERM. European Reference Materials-BD150. 2020. Available online: https://crm.jrc.ec.europa.eu/?q=ERMBD150 (accessed on 24 March 2020).

26. ERM. European Reference Materials-CD281. 2020. Available online: https://crm.jrc.ec.europa.eu/p/q/ERMCD281/ERM-CD281-RYE-GRASS/ERM-CD281 (accessed on 24 March 2020).

27. ATSDR. Toxicological Profile for Cadmium; U.S. Department of Health and Human Services, Public Health Service, Eds.; Agency for Toxic Substances and Disease Registry: Atlanta, GA, USA, 2012.

28. McLellan, J.S.; Flanagan, P.R.; Chamberlain, M.J.; Valberg, L.S. Measurement of dietary cadmium absorption in humans. J. Toxicol. Environ. Health 1978, 4, 131-138. [CrossRef] [PubMed]

29. Flanagan, P.R.; McLellan, J.S.; Haist, J.; Cherian, G.; Chamberlain, M.J.; Valberg, L.S. Increased dietary cadmium absorption in mice and human subjects with iron deficiency. Gastroenterology 1978, 74, 841-846. [CrossRef]

30. Berglund, M.; Akesson, A.; Nermell, B.; Vahter, M. Intestinal absorption of dietary cadmium in women depends on body iron stores and fiber intake. Environ. Health Perspect 1994, 102, 1058-1066. [CrossRef]

31. Jarup, L.; Rogenfelt, A.; Elinder, C.G.; Nogawa, K.; Kjellstrom, T. Biological half-time of cadmium in the blood of workers after cessation of exposure. Scand J. Work Environ. Health 1983, 9, 327-331. [CrossRef] 
32. National Cancer Institute. NCI Dictionary of Cancer Terms: Pack Year. 2019. Available online: https: //www.cancer.gov/publications/dictionaries/cancer-terms/def/pack-year (accessed on 24 March 2020).

33. Masters, N.; Tutt, C. Smoking Pack Years Calculator. 2019. Available online: https://www.smokingpackyears. com (accessed on 24 March 2020).

34. Barregard, L.; Bergstrom, G.; Fagerberg, B. Cadmium, type 2 diabetes, and kidney damage in a cohort of middle-aged women. Environ. Res. 2014, 135, 311-316. [CrossRef]

35. Thomas, L.D.; Elinder, C.G.; Wolk, A.; Akesson, A. Dietary cadmium exposure and chronic kidney disease: A population-based prospective cohort study of men and women. Int. J. Hyg. Environ. Health 2014, 217, 720-725. [CrossRef]

36. Alessio, L.; Apostoli, P.; Forni, A.; Toffoletto, F. Biological monitoring of cadmium exposure-An Italian experience. Scand. J. Work Environ. Health 1993, 19 (Suppl. 1), 27-33.

37. Madeddu, R.; Muresu, E.; Montella, A.; Chessa, G.; Cherchi, G.B.; Piras, P.; Vargiu, P.; Tolu, P.; Pirino, A.; Prados, J.C.; et al. Low cadmium concentration in whole blood from residents of northern Sardinia (Italy) with special reference to smoking habits. J. Prev. Med. Hyg. 2009, 50, 46-52. [PubMed]

38. Jain, R.B. Factors affecting the variability in the observed levels of cadmium in blood and urine among former and current smokers aged 20-64 and >/=65years. Environ. Sci. Pollut. Res. Int. 2017, 24, 8837-8851. [CrossRef] [PubMed]

39. Julin, B.; Vahter, M.; Amzal, B.; Wolk, A.; Berglund, M.; Akesson, A. Relation between dietary cadmium intake and biomarkers of cadmium exposure in premenopausal women accounting for body iron stores. Environ. Health 2011, 10, 105. [CrossRef] [PubMed]

40. Reeves, P.G.; Chaney, R.L. Mineral status of female rats affects the absorption and organ distribution of dietary cadmium derived from edible sunflower kernels (Helianthus annuus L.). Environ. Res. 2001, 85, 215-225. [CrossRef] [PubMed]

41. Kippler, M.; Goessler, W.; Nermell, B.; Ekstrom, E.C.; Lonnerdal, B.; El Arifeen, S.; Vahter, M. Factors influencing intestinal cadmium uptake in pregnant Bangladeshi women-a prospective cohort study. Environ. Res. 2009, 109, 914-921. [CrossRef] [PubMed]

42. Vinceti, M.; Filippini, T.; Wise, L.A. Environmental Selenium and Human Health: An Update. Curr. Environ. Health Rep. 2018, 5, 464-485. [CrossRef]

43. Johansson, G.; Akesson, A.; Berglund, M.; Nermell, B.; Vahter, M. Validation with biological markers for food intake of a dietary assessment method used by Swedish women with three different dietary preferences. Public Health Nutr. 1998, 1, 199-206. [CrossRef]

44. Vacchi-Suzzi, C.; Kruse, D.; Harrington, J.; Levine, K.; Meliker, J.R. Is Urinary Cadmium a Biomarker of Long-term Exposure in Humans? A Review. Curr. Environ. Health Rep. 2016, 3, 450-458. [CrossRef]

45. Amzal, B.; Julin, B.; Vahter, M.; Wolk, A.; Johanson, G.; Akesson, A. Population toxicokinetic modeling of cadmium for health risk assessment. Environ. Health Perspect. 2009, 117, 1293-1301. [CrossRef]

46. McElroy, J.A.; Shafer, M.M.; Hampton, J.M.; Newcomb, P.A. Predictors of urinary cadmium levels in adult females. Sci. Total Environ. 2007, 382, 214-223. [CrossRef]

47. Shimbo, S.; Zhang, Z.W.; Moon, C.S.; Watanabe, T.; Nakatsuka, H.; Matsuda-Inoguchi, N.; Higashikawa, K.; Ikeda, M. Correlation between urine and blood concentrations, and dietary intake of cadmium and lead among women in the general population of Japan. Int. Arch. Occup. Environ. Health 2000, 73, 163-170. [CrossRef] [PubMed]

48. Adams, S.V.; Quraishi, S.M.; Shafer, M.M.; Passarelli, M.N.; Freney, E.P.; Chlebowski, R.T.; Luo, J.; Meliker, J.R.; $\mathrm{Mu}$, L.; Neuhouser, M.L.; et al. Dietary cadmium exposure and risk of breast, endometrial, and ovarian cancer in the Women's Health Initiative. Environ. Health Perspect. 2014, 122, 594-600. [CrossRef] [PubMed]

49. Moon, C.S.; Zhang, Z.W.; Shimbo, S.; Watanabe, T.; Lee, C.U.; Lee, B.K.; Ahn, K.D.; Lee, S.H.; Ikeda, M. Evaluation of urinary cadmium and lead as markers of background exposure of middle-aged women in Korea: Dietary intake as an influential factor. Toxicol. Lett. 1999, 108, 173-178. [CrossRef]

50. Kobayashi, E.; Suwazono, Y.; Uetani, M.; Inaba, T.; Oishi, M.; Kido, T.; Nakagawa, H.; Nogawa, K. Association between lifetime cadmium intake and cadmium concentration in individual urine. Bull. Environ. Contam. Toxicol. 2005, 74, 817-821. [CrossRef] [PubMed]

51. Ikeda, M.; Nakatsuka, H.; Watanabe, T.; Shimbo, S. Estimation of daily cadmium intake from cadmium in blood or cadmium in urine. Environ. Health Prev. Med. 2015, 20, 455-459. [CrossRef] 
52. Ikeda, M.; Nakatsuka, H.; Watanabe, T.; Shimbo, S. Estimation of dietary intake of cadmium from cadmium in blood or urine in East Asia. J. Trace Elem. Med. Biol. 2018, 50, 24-27. [CrossRef]

53. Choudhury, H.; Harvey, T.; Thayer, W.C.; Lockwood, T.F.; Stiteler, W.M.; Goodrum, P.E.; Hassett, J.M.; Diamond, G.L. Urinary cadmium elimination as a biomarker of exposure for evaluating a cadmium dietary exposure-Biokinetics model. J. Toxicol. Environ. Health A 2001, 63, 321-350. [CrossRef]

54. Vinceti, M.; Chiari, A.; Eichmuller, M.; Rothman, K.J.; Filippini, T.; Malagoli, C.; Weuve, J.; Tondelli, M.; Zamboni, G.; Nichelli, P.F.; et al. A selenium species in cerebrospinal fluid predicts conversion to Alzheimer's dementia in persons with mild cognitive impairment. Alzheimers Res. Ther. 2017, 9, 100. [CrossRef]

55. Ferrante, G.; Minardi, V.; Possenti, V.; Quarchioni, E.; Masocco, M.; Salmaso, S.; Braggion, M.; Campostrini, S.; Baldissera, S.; Gruppo Tecnico PASSI. Smoke: Prevalence is decreasing, but the gap between socioeconomic categories remains. Epidemiol. Prev. 2012, 36, 371.

56. Gruppo Tecnico PASSI. Emilia-Romagna, Sovrappeso e obesità in Emilia-Romagna: Dati del sistema di sorveglianza PASSI (anni 2008-2011). 2012. Available online: http://www.epicentro.iss.it/passi/pdf2012/ EccessoPond_PassiER_08_11.pdf (accessed on 24 March 2020).

57. Sirot, V.; Samieri, C.; Volatier, J.L.; Leblanc, J.C. Cadmium dietary intake and biomarker data in French high seafood consumers. J. Expo. Sci. Environ. Epidemiol. 2008, 18, 400-409. [CrossRef]

58. Turconi, G.; Minoia, C.; Ronchi, A.; Roggi, C. Dietary exposure estimates of twenty-one trace elements from a Total Diet Study carried out in Pavia, Northern Italy. Br. J. Nutr. 2009, 101, 1200-1208. [CrossRef]

59. Madeddu, R.; Solinas, G.; Forte, G.; Bocca, B.; Asara, Y.; Tolu, P.; Delogu, L.G.; Muresu, E.; Montella, A.; Castiglia, P. Diet and nutrients are contributing factors that influence blood cadmium levels. Nutr. Res. 2011, 31, 691-697. [CrossRef] [PubMed]

60. Satarug, S.; Vesey, D.A.; Gobe, G.C. Current health risk assessment practice for dietary cadmium: Data from different countries. Food Chem. Toxicol. 2017, 106, 430-445. [CrossRef] [PubMed]

61. Sand, S.; Becker, W. Assessment of dietary cadmium exposure in Sweden and population health concern including scenario analysis. Food Chem. Toxicol. 2012, 50, 536-544. [CrossRef] [PubMed]

62. Nawrot, T.S.; Staessen, J.A.; Roels, H.A.; Munters, E.; Cuypers, A.; Richart, T.; Ruttens, A.; Smeets, K.; Clijsters, H.; Vangronsveld, J. Cadmium exposure in the population: From health risks to strategies of prevention. Biometals 2010, 23, 769-782. [CrossRef] [PubMed] 